\title{
Localization of Cells Synthesizing Transforming Growth Factor-Alpha mRNA in the Mouse Brain
}

\author{
Josiah N. Wilcox and Rik Derynck \\ Department of Molecular Biology, Genentech, Inc., South San Francisco, California 94080
}

\begin{abstract}
The distribution of transforming growth factor (TGF)- $\alpha$ and TGF- $\beta_{1}$ mRNA containing cells in adult mouse brain was examined using in situ hybridization histochemistry. There were no detectable TGF- $\beta$, mRNA-containing cells found in the brain. TGF- $\alpha$ mRNA was localized to cell bodies of the caudate nucleus, dentate gyrus, anterior olfactory nuclei, and a laminar distribution of mitral cells in the olfactory bulb. TGF$\alpha$-synthesizing cells were localized in brain regions that have been shown to synthesize nerve growth factor, epidermal growth factor (EGF) and enkephalins. The function of local synthesis of TGF- $\alpha$ in the brain is as yet unknown.
\end{abstract}

Transforming growth factors (TGFs) were originally defined as polypeptides that induce the phenotypic transformation of a variety of normal cell lines (De Larco and Todaro, 1978). Two different proteins have been described as transforming growth factors, TGF- $\alpha$ and TGF- $\beta$. TGF- $\alpha$ displays structural homology with epidermal growth factor (EGF) (Marquardt et al., 1984) and binds to the EGF receptor (Carpenter et al., 1983; Massague, 1983). Several molecular-weight forms of secreted TGF- $\alpha$ have been described. The fully processed 50 -amino acid form and the larger glycosylated forms are all derived from the transmembrane precursor (Bringman et al., 1987). TGF- $\alpha$ and EGF have similar biological activities and appear to be equally mitogenic for several cell lines (Massague, 1983; Derynck et al., 1984; Bringman et al., 1987), yet TGF- $\alpha$ appears to function as a superagonist in several systems (Stern et al., 1985; Ibbotson et al., 1986; Schreiber et al., 1986). TGF- $\beta$ is structurally unrelated to TGF- $\alpha$ or EGF and is a homodimeric protein (Assoian et al., 1983; Derynck et al., 1985) that interacts with distinct receptors (Massague, 1985; Cheifetz et al., 1986). It is mitogenic for a variety of normal fibroblast lines, but inhibits the growth of several other normal cell types and many tumor cells (Moses et al., 1985; Roberts et al., 1985).

The presence of TGF- $\alpha$ was originally detected in the medium of several retrovirus-transformed fibroblasts, and its synthesis was later documented in several tumor cell lines (Todaro et al., 1985). A recent survey revealed the expression of the TGF- $\alpha$ gene in a wide variety of carcinomas and sarcomas, but not in hematopoietic tumor cells (Derynck et al., 1987). TGF- $\alpha$ gene expression has been detected during early fetal development (Twardzik, 1985), and, recently, low levels of TGF- $\alpha$ mRNA have been found in the brain, liver and kidney of the adult rat

\footnotetext{
Received Apr. 1, 1987; revised Aug. 27, 1987; accepted Oct. 30, 1987.

Correspondence should be addressed to Josiah N. Wilcox, Department of Cardiovascular Research, Genentech, Inc., 460 Point San Bruno Boulevard, South San Francisco, CA 94080.

Copyright $(C) 1988$ Society for Neuroscience $0270-6474 / 88 / 061901-04 \$ 02.00 / 0$
}

(Lee et al., 1985). Compared to TGF- $\alpha$, TGF- $\beta$ synthesis is more ubiquitous, since most, if not all, normal or transformed cells in culture release TGF- $\beta$ (see, e.g., Derynck et al., 1985).

\section{Materials and Methods}

Mouse brains were processed for in situ hybridization using a modification of previous methods (Wilcox et al., 1986a, b). The animals were killed by cervical dislocation, the brains removed and fixed by immersion in $4 \%$ paraformaldehyde for $3 \mathrm{hr}$, followed by immersion in $15 \%$ sucrose overnight at $4^{\circ} \mathrm{C}$. The brains were then frozen and $10 \mu \mathrm{m}$ sagittal sections were taken every $100 \mu \mathrm{m}$ for hybridization to a murine TGF$\alpha$-specific probe. The murine TGF- $\alpha$-specific probe was a 1400 bp genomic Sau3A fragment, corresponding to a segment in the sixth exon of the TGF- $\alpha$ gene. This segment in the $3^{\prime}$-untranslated region has its most upstream residue 6 bases $3^{\prime}$ to the stop codon. The Sau $3 \mathrm{~A}$ fragment was subcloned in the BamHI site of the plasmid sp64 in the antisense orientation with respect to the transcriptional direction from the sp6 promoter. This probe has been used in Northern blots and recognizes a $5.0 \mathrm{~kb}$ TGF- $\alpha$ mRNA species in ras-transformed mammary epithelial cells (Salomon et al., 1987). Serial sections were also hybridized to a murine TGF- $\beta$ riboprobe. The murine TGF- $\beta$ probe was the $E c o$ RI fragment of pMur $\beta_{2}$ (Derynck et al., 1986), corresponding to a cDNA containing the entire coding sequence for the TGF- $\beta_{1}$ precursor. This $1600 \mathrm{bp}$ fragment was inserted into the $E c o$ RI site of plasmid sp65 in the antisense orientation with respect to the transcriptional direction from the sp6 promoter. As controls for positive chemography, additional sections were carried through the hybridization procedure without adding any radioactive probe to the hybridization mixture.

The hybridization probes were specific ${ }^{35} \mathrm{~S}$-labeled RNA transcripts complementary to the mRNA obtained after in vitro transcription of the cDNA insert from linearized plasmids using sp6-RNA polymerase. The transcription procedure was modified from Melton et al. (1984). The transcription mixture contained a final concentration of $500 \mu \mathrm{M}$ each of the nucleotides cytidine 5'-triphosphate (CTP), guanosine 5 'triphosphate (GTP), uridine triphosphate (UTP), and $12 \mu \mathrm{M}{ }^{35} \mathrm{~S}-\mathrm{ATP}$ (Amersham; sp act, $650 \mathrm{Ci} / \mathrm{mmol}$ ), 40 units of RNasin (Promega Biotech), $2 \mathrm{~mm}$ spermidine, $10 \mathrm{~mm}$ dithiothreitol (DTT), $10 \mathrm{~mm} \mathrm{NaCl}, 40$ $\mathrm{mm}$ Tris, $\mathrm{pH} 7.5$, and was initiated by the addition of 15 units of sp6RNA polymerase. The reaction proceeded for $2 \mathrm{hr}$ at $37^{\circ} \mathrm{C}$, followed by DNase digestion of the template (RQI DNase; Promega Biotech), phe$\mathrm{nol} /$ chloroform extraction, and ethanol precipitation. The specific activity of probes synthesized by this method was $162.5 \mathrm{Ci} / \mathrm{mmol}$, or approximately $10^{9} \mathrm{cpm} / \mu \mathrm{g}$.

Hybridizations were carried out as described previously (Cox et al., 1984; Wilcox et al., 1986a), except for some modifications necessary for the use of the ${ }^{35} \mathrm{~S}$-labeled RNA probes. These included using a hybridization buffer containing $50 \%$ formamide, $0.3 \mathrm{M} \mathrm{NaCl}, 20 \mathrm{~mm}$ Tris, $\mathrm{pH} 8.0,5 \mathrm{~mm}$ EDTA, $1 \times$ Denhardt solution, $10 \%$ dextran sulfate, and $10 \mathrm{~mm}$ DTT, and $2000 \mathrm{cpm} / \mu \mathrm{l}{ }^{35} \mathrm{~S}$-labeled riboprobe. Hybridization was allowed to proceed for $18-20 \mathrm{hr}$ at $50^{\circ} \mathrm{C}$. After hybridization, the slides were washed twice for $10 \mathrm{~min}$ in $2 \times \mathrm{SSC}(1 \times \mathrm{SSC}=150 \mathrm{~mm}$

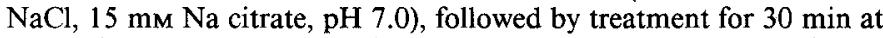
$22{ }^{\circ} \mathrm{C}$ with $20 \mu \mathrm{g} / \mathrm{ml}$ RNase A (Sigma Chemical), washing $2 \times$ for 10 $\min$ in $2 \times \mathrm{SSC}$, for $2 \mathrm{hr}$ in $0.2 \times \mathrm{SSC}$ at $42^{\circ} \mathrm{C}$, and finally twice for 10 min in $0.5 \times \mathrm{SSC}$ at $22^{\circ} \mathrm{C}$. All posthybridization washes, except for the final washes in $0.5 \times \mathrm{SSC}$, contained $10 \mathrm{~mm} \beta$-mercaptoethanol and 1 mM EDTA. ${ }^{35} \mathrm{~S}$-Labeling of the RNA probes proved to be necessary 

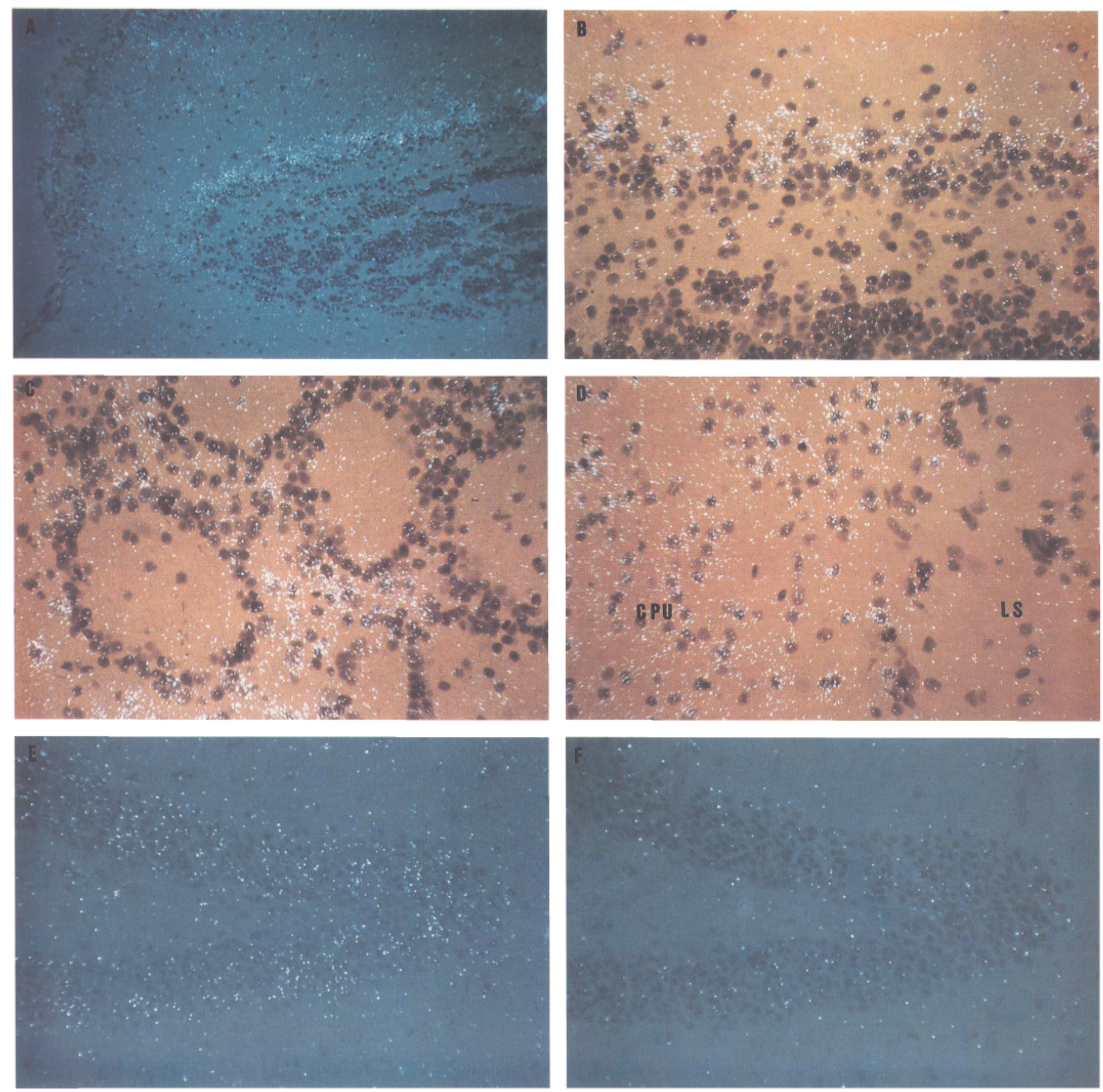

Figure 1. Results from in situ hybridizations of mouse brain sections to ${ }^{35}$ S-labeled TGF- $\alpha(A-E)$ or TGF- $\beta(F)$ riboprobe. Sagittal sections $(10$ $\mu \mathrm{m})$ were hybridized and washed as described and coated with Kodak NTB2 nuclear emulsion. Autoradiograms were exposed for 4 weeks at $4^{\circ} \mathrm{C}$ in the dark and after developing were counterstained with hematoxylin and eosin. Silver grains were visualized by either polarized light epiluminescence (Leitz) alone $(A, E, F)$ or in combination with bright-field illumination $(B-D)$. Positive TGF- $\alpha$ hybridizations are shown for the olfactory bulb $(A ; \times 100)$, mitral cells of olfactory bulb $(B ; \times 310)$, periglomerular cells of the olfactory bulb $(C ; \times 310)$, the caudate nucleus $(D ; \times 310)$, and the dentate gyrus $(E ; \times 310)$. A serial section of the dentate gyrus hybridized to ${ }^{35}$ S-labeled TGF- $\beta$ riboprobe showed no hybridizing cells $(F ; \times 100)$ and provides a useful control for the TGF- $\alpha$ hybridizations. Elevated grain densities apparent in $A-D$ are due to the use of ${ }^{35} S$-labeled ATP and UTP in the transcription reaction, which results in a higher specific-activity probe. Abbreviations: $C P U$, caudate nucleus; $L S$, lateral septum.

since no detectable hybridization was obtained using similar ${ }^{3} \mathrm{H}-\mathrm{RNA}$ probes.

After hybridization and washing, the slides were dehydrated in graded alcohols containing $0.3 \mathrm{M} \mathrm{NH}_{4} \mathrm{AC}$, dried under vacuum, and then coated with Kodak NTB2 nuclear emulsion diluted 1:1 with water. Autoradiograms were exposed for 4 weeks with desiccant at $4^{\circ} \mathrm{C}$ in the dark. The slides were developed at $15^{\circ} \mathrm{C}$ with Kodak D19 developer (1:1 dilution) and Kodak fixer, and counterstained with hematoxylin and eosin.

\section{Results}

Examination of the autoradiographic results of the histological sections after in situ hybridization revealed that several areas 


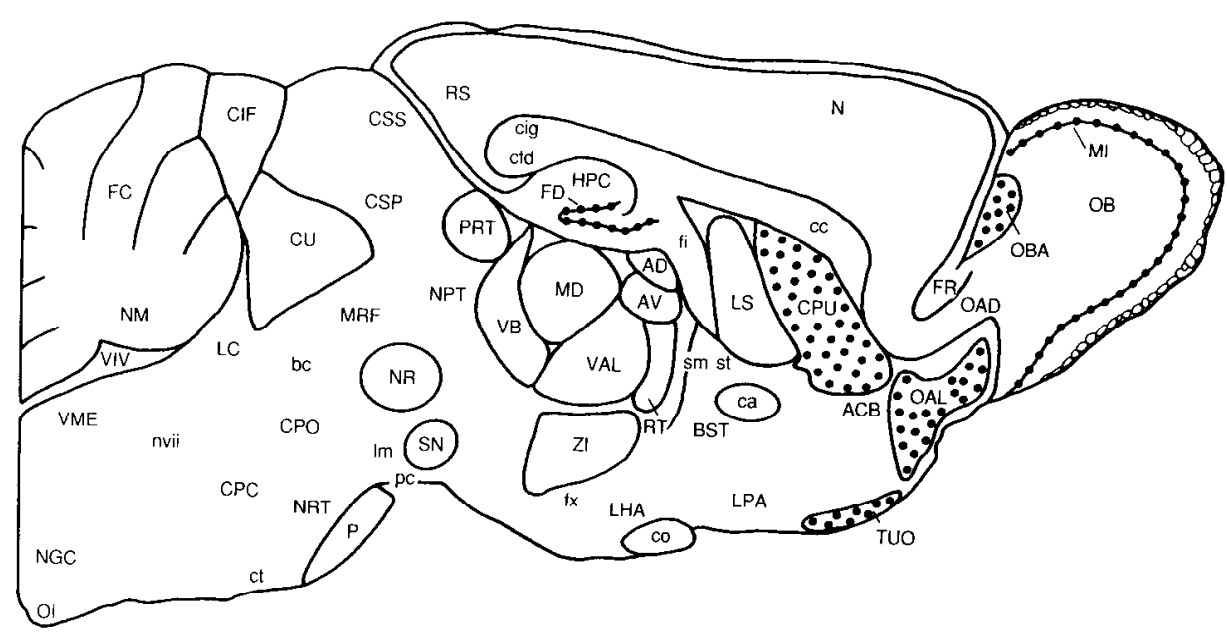

Figure 2. Schematic diagram summarizing the results of TGF- $\alpha$ in situ hybridizations in mouse brain. Dotted regions indicate TGF- $\alpha$-synthesizing regions, which included dentate gyrus $(F D)$, caudate nucleus $(C P U)$, anterior olfactory nucleus $(O A L)$, tuber olfactorium $(T U O)$, mitral cell layer $(M I)$, and accessory olfactory bulb $(O B A)$. Not shown are hybridizations to the perioglomerular cells of the olfactory bulb. Abbreviations and drawing after Slotnick and Leonard (1975). in the brain (Fig. 1) have a low, yet significant, expression of the TGF- $\alpha$ gene. These results are summarized in Figure 2 by a schematic representation of the sites of TGF- $\alpha$ expression in the adult mouse brain. Cell bodies hybridizing to the TGF- $\alpha$ probe were found in the caudate nucleus (Fig. $1 D$ ), dentate gyrus (Fig. 1E), the dorsal, medial, and lateral extents of the anterior olfactory nuclei, accessory olfactory bulb, and the tuberculum olfactorium (data not shown). Consistent labeling was also found in many periglomerular (Fig. 1C) and mitral (Fig. 1B) cells of the olfactory bulb, the latter cells forming a laminar cell group adjacent to the granular cell layer (Fig. $1 A$ ). Scattered labeling of cells was also seen in cells of the external plexiform layer of the olfactory bulb.

The labeling of cells by TGF- $\alpha$ in situ hybridization appeared to be predominantly neuronal. Labeling was in a population of cells with large nuclei. The mitral cell labeling was consistent; these cells also have large nuclei with a characteristic morphology. It should be noted, however, that it is not possible to exclude the possibility that glial cells could also make TGF- $\alpha$ mRNA.

All TGF- $\alpha$ hybridizations were performed in parallel with hybridizations of serial sections to a TGF- $\beta$-specific probe. This probe was labeled to the same specific activity as was the TGF- $\alpha$ probe, and the same amount of probe was added to the hybridization solutions. While the TGF- $\beta$ probe was effective in in situ hybridizations in unrelated histological sections (data not shown), there were no specific hybridizations detected in the adult brain. Our data thus lead to the conclusion that TGF- $\beta$ is not expressed at detectable levels in the adult brain. This lack of hybridization of the TGF- $\beta$ probe provided a useful control for the TGF- $\alpha$-specific hybridization and supports the specificity of the results obtained with the TGF- $\alpha$ probe (Fig. 1, $E$ vs $F$ ). The specificity was further supported by other controls, one for positive chemography, where sections were carried through the hybridization procedure without the addition of any labeled probe, and another where sections were pretreated with $20 \mu \mathrm{g} /$ $\mathrm{ml}$ RNase A prior to hybridization to the TGF- $\alpha$ probe. There were no hybridizing cells seen with either treatmont (data not shown).

\section{Discussion}

In this report we describe the localization of the cell populations that synthesize TGF- $\alpha$ in the normal mouse brain and thus establish the expression of the TGF- $\alpha$ gene in vivo in a normal organ of an adult animal. We also report that TGF- $\beta_{1}$ mRNA could not be detected in the adult brain.

Analysis by Northern blot hybridization had previously suggested the presence of TGF- $\alpha$ mRNA in the brain (Lee et al., 1985). We have now identified the cell types and areas in the adult mouse brain that synthesize TGF- $\alpha$. The localization in the adult brain of 2 other growth factors has been described. NGF has been shown by Northern blots to be synthesized in the hippocampus (Shelton and Reichardt, 1986), as well as by in situ hybridization localized to the dentate gyrus (Rennert and Heinrich, 1986), an area that we have now shown contains TGF- $\alpha$ mRNA as well. The presence of EGF, which is structurally related to TGF- $\alpha$, has been demonstrated by immunohistochemistry in the globus pallidus, ventral palladium, and other forebrain structures (Fallon et al., 1984). These regions receive efferent innervation from the caudate nucleus, which we have shown to synthesize TGF- $\alpha$.

The finding that there is TGF- $\alpha$ gene expression in the brain raises the question of the physiological role of TGF- $\alpha$ in this tissue. In a variety of cell types in culture and presumably also in vivo, TGF- $\alpha$ and EGF bind to the EGF receptor, and in this way exert their mitogenic effect. However, it is unlikely that TGF- $\alpha$ acts as a mitogen in the brain, since there is very little cell division in this organ. TGF- $\alpha$ may act as a chemotactic or a neurotrophic agent, and thus play a role in dendritic sprouting or arborization. TGF- $\alpha$ may also have other neuromodulatory functions that have yet to be demonstrated.

The expression of the TGF- $\alpha$ gene in mitral and periglomerular cells of the olfactory bulb and in the anterior olfactory nucleus and tuberculum olfactorium suggests that this peptide is somehow involved in olfactory processes. Olfactory information enters the brain via the olfactory nerve, whose axons form synapses upon dendrites of the mitral and tufted cells in the glomeruli of the olfactory bulb. The periglomerular cells are a heterogeneous group of interneurons that modify mitral and tufted cell output. The periglomerular cells, which apparently contain TGF- $\alpha$ mRNA, have becn shown to use both substance $P$ and enkephalins as neurotransmitters (Finley et al., 1981; Halasz and Shepherd, 1983). These neurotransmitters are also prevalent in the caudate nucleus and dentate gyrus (Sar et al., 1978; Finley et al., 1981), which also show TGF- $\alpha$-specific hybridization. There may thus be a colocalization of enkephalin and TGF- $\alpha$ 
in some areas. However, this does not hold for the presence of TGF- $\alpha$ mRNA in the mitral cells of the olfactory bulb, as these cells do not use enkephalin, but rather glutamate or aspartate, as a neurotransmitter (Macrides and Davis, 1983). The mitral cells do, however, receive enkephalinergic inputs from the periglomerular cells. It is therefore possible that TGF- $\alpha$ plays a role in the cells that receive enkephalinergic information. Further research will be needed to investigate the role of TGF- $\alpha$ in the brain and to evaluate its possible interactions with other growth factors and neurotransmitters.

\section{References}

Assoian, R. K., A. Komoriya, C. A. Meyers, D. Miller, and M. B. Sporn (1983) Transforming growth factor- $\beta$ in human platelets. Identification of a major storage site, purification and characterization. $J$. Biol. Chem. 258: 7155-7160.

Bringman, T. S., P. B. Lindquist, and R. Derynck (1987) Different transforming growth factor- $\alpha$ species are derived from a glycosylated and palmitoylated transmembrane precursor. Cell 48: 429-440.

Carpenter, G., C. M. Stoscheck, Y. A. Preston, and J. E. De Larco (1983) Antibodies to the epidermal growth factor receptor block the biological activities of sarcoma growth factor. Proc. Natl. Acad. Sci. USA 80: 5627-5630.

Cheifetz, S., B. Like, and J. Massague (1986) Cellular distribution of type I and type II receptor for transforming growth factor- $\beta$. J. Biol. Chem. 261: 9972-9978.

Cox, K. H., D. V. DeLeon, L. M. Angerer, and R. C. Angerer (1984) Detection of mRNAs in sea urchin embryos by in situ hybridization using asymmetric RNA probes. Dev. Biol. 101: 485-502.

De Larco, J. E., and G. J. Todaro (1978) Growth factors from murine sarcoma virus-transformed cells. Proc. Natl. Acad. Sci. USA 75:40014005 .

Derynck, R., A. B. Roberts, M. E. Winkler, E. Y. Chen, and D. V. Goeddel (1984) Human transforming growth factor- $\alpha$ : Precursor structure and expression in E. coli. Cell 38: 287-297.

Derynck, R., J. A. Jarrett, E. Y. Chen, D. H. Eaton, J. R. Bell, R. K. Assoian, A. B. Roberts, M. B. Sporn, and D. V. Goeddel (1985) Human transforming growth factor $-\beta$ cDNA sequence and expression in tumor cell lines. Nature 316: 701-705.

Derynck, R., J. A. Jarrett, E. Y. Chen, and D. V. Goeddel (1986) The murine transforming growth factor- $\beta$ precursor. J. Biol. Chem. 216: $4377-4379$.

Derynck, R., D. V. Goeddel, A. Ullrich, J. U. Gutterman, R. D. Williams, T.S. Bringman, and W. H. Berger (1987) Synthesis of mRNAs for transforming growth factors- $\alpha$ and $-\beta$ and the epidermal growth factor receptor by human tumors. Cancer Res. 47: 707-712.

Fallon, J. H., K. B. Seroogy, S. E. Loughlin, R. S. Morrison, R. A. Bradshaw, D. J. Knauer, and D. D. Cunningham (1984) Epidermal growth factor immunoreactive material in the central nervous system: Location and development. Science 224: 1107-1109.

Finley, J. C. W., J. L. Maderdrut, and P. Petrusz (1981) The immunocytochemical localization of enkephalin in the central nervous system of the rat. J. Comp. Neurol. 198: 541.

Halasz, N., and G. M. Shepherd (1983) Neurochemistry of the vertebrate olfactory bulb. Neuroscience 10:759-619.

Ibbotson, K. J., J. Harrod, M. Gowen, S. D'Souza, M. E. Winkler, R. Derynck, and G. R. Mundy (1986) Human recombinant transforming growth factor- $\alpha$ stimulates bone resorption and inhibits formation in vitro. Proc. Natl. Acad. Sci. USA 83: 2228-2232.

Lee, D. C., R. Rochford, G. J. Todaro, and L. P. Villareal (1985) Developmental expression of rat transforming growth factor- $\alpha$ mRNA. Mol. Cell. Biol. 5: 3644-3646.
Macrides, F., and B. J. Davis (1983) The olfactory bulb. In Chemical Neuroanatomy, P. C. Emson, ed., pp. 391-426, Raven, New York.

Marquardt, H., M. W. Hunkapiller, L. E. Hood, and G. J. Todaro (1984) Rat transforming growth factor type 1 structure and relation to epidermal growth factor. Science 223: 1079-1082.

Massague, J. (1983) Epidermal growth factor-like transforming growth factor: Interaction with epidermal growth factor receptors in human placenta membranes and A431 cells. J. Biol. Chem. 258: 1361413620.

Massague, J. (1985) Subunit structure of a high affinity receptor for type $\beta$-transforming growth factor. Evidence for a disulfide-linked glycosylated receptor complex. J. Biol. Chem. 260: 7059-7066.

Melton, D. A., P. A. Krieg, M. R. Rebagliati, T. Maniatis, K. Zinn, and M. R. Green (1984) Efficient in vitro synthesis of biologically active RNA and RNA hybridization probes from plasmids containing a bacteriophage. Nucleic Acids Res. 12: 7035-7056.

Moses; H. L., R. F. Tucker, E. B. Leof, R. J. Coffey, J. Halper, and G. D. Shipley (1985) Type- $\beta$ transforming growth factor is a growth stimulator and a growth inhibitor. In Cancer Cells, vol. 3, pp. 6571, Cold Spring Harbor Laboratory, New York.

Rennert, P. D., and G. Heinrich (1986) Nerve growth factor mRNA in brain: Localization by in situ hybridization. Biochem. Biophys. Res. Commun. 138: 813-818.

Roberts, A. B., M. A. Anzano, L. A. Wakefield, N. S. Roche, D. F. Stern, and M. B. Sporn (1985) Type $\beta$ transforming growth factor: A bifunctional regulator of cellular growth. Proc. Natl. Acad. Sci. USA $82: 119-123$.

Salomon, D. S., I. Perroteau, W. R. Kidwell, J. Tam, and R. Derynck (1987) Loss of growth responsiveness to epidermal growth factor and enhanced production of alpha-transforming growth factors in rastransformed mouse mammary epithelial cells. J. Cell. Physiol. 130: $397-409$.

Sar, M., W. E. Stumpf, R. J. Miller, K.-J. Chang, and P. Cuatrecasas (1978) Immunohistochemical localization of enkephalin in rat brain and spinal cord. J. Comp. Neurol. 182: 17-38.

Schreiber, A. B., M. E. Winkler, and R. Derynck (1986) Transforming growth factor- $\alpha$ is a more potent angiogenic mediator than epidermal growth factor. Science 232: $1250-1253$.

Shelton, D. L., and L. F. Reichardt (1986) Studies on the expression of the $\beta$ nerve growth factor (NGF) gene in the central nervous system: Level and regional distribution of NGF mRNA suggest that NGF functions as a trophic factor for several distinct populations' neurons. Proc. Natl. Acad. Sci. USA 83: 2714-2718.

Slotnick, B. M., and C. M. Leonard (1975) A Stereotaxic Atlas of the Albino Mouse Forebrain, U.S. Dept. HEW, Rockville, MD.

Stern, P. H., N. S. Krieger, R. A. Nissenson, R. D. Williams, M. E. Winkler, R. Derynck, and G. J. Shewler (1985) Human transforming growth factor- $\alpha$ stimulates bone resorption in vitro. J. Clin. Invest. 76: 2016-2019.

Todaro, G. J., D. C. Lee, N. R. Webb, T. M. Rose, and J. P. Brown (1985) Rat type- $\alpha$ transforming growth factor: Structure and possible function as a transmembrane receptor. In Cancer Cells, vol. 3, pp. 51-58, Cold Spring Harbor Laboratory, New York.

Twardzik, D. R. (1985) Differential expression of transforming growth factor- $\alpha$ during prenatal development of the mouse. Cancer Res. 45: 5413-5416.

Wilcox, J. N., J. L. Roberts, B. M. Chronwall, J. F. Bishop, and T. O'Donohue (1986a) Localization of proopiomelanocortin mRNA in functional subsets of neurons defined by their axonal projections. J. Neurosci. Res. 16: 89-96.

Wilcox, J. N., C. E. Gee, and J. L. Roberts (1986b) In situ cDNA: mRNA hybridization: Development of a technique to measure mRNA levels in individual cells. Methods Enzymol. 125: 510-533. 